AperTO - Archivio Istituzionale Open Access dell'Università di Torino

\title{
Bioprospecting bacterial and fungal volatiles for sustainable agriculture
}

\section{This is the author's manuscript}

Original Citation:

Availability:

This version is available http://hdl.handle.net/2318/154259

since 2019-06-11T11:52:50Z

Published version:

DOI:10.1016/j.tplants.2015.01.004

Terms of use:

Open Access

Anyone can freely access the full text of works made available as "Open Access". Works made available under a Creative Commons license can be used according to the terms and conditions of said license. Use of all other works requires consent of the right holder (author or publisher) if not exempted from copyright protection by the applicable law. 
This Accepted Author Manuscript (AAM) is copyrighted and published by Elsevier. It is posted here by agreement between Elsevier and the University of Turin. Changes resulting from the publishing process - such as editing, corrections, structural formatting, and other quality control mechanisms - may not be reflected in this version of the text. The definitive version of the text was subsequently published in TRENDS IN PLANT SCIENCE, 20 (4), 2015, 10.1016/j.tplants.2015.01.004.

You may download, copy and otherwise use the AAM for non-commercial purposes provided that your license is limited by the following restrictions:

(1) You may use this AAM for non-commercial purposes only under the terms of the CC-BY-NC-ND license.

(2) The integrity of the work and identification of the author, copyright owner, and publisher must be preserved in any copy.

(3) You must attribute this AAM in the following format: Creative Commons BY-NC-ND license (http://creativecommons.org/licenses/by-nc-nd/4.0/deed.en), 10.1016/j.tplants.2015.01.004

The publisher's version is available at:

http://linkinghub.elsevier.com/retrieve/pii/S1360138515000059

When citing, please refer to the published version.

Link to this full text:

http://hdl.handle.net/2318/154259 


\title{
Bioprospecting bacterial and fungal volatiles for sustainable agriculture
}

Chidananda Nagamangala Kanchiswamy ${ }^{1 *}$, Mickael Malnoy ${ }^{1}$, Massimo E. Maffei $^{2}$

${ }^{1}$ Research and Innovation Centre Genomics and Biology of Fruit Crop Department, Fondazione Edmund Mach (FEM), Istituto Agrario San Michele (IASMA), Via Mach 1, 38010 San Michele all'Adige (TN), Italy; E-Mail: mickael.malnoy@fmach.it (MM)

${ }^{2}$ Department of Life Sciences and Systems Biology, Innovation Centre, University of Turin, Via Quarello 15/A, 10135 Turin, Italy; E-Mail: massimo.maffei@unito.it (MEM)

*To whom correspondence should be addressed: E-mail: chidananda.nagamangala@fmach.it ; Tel.: +3904616151 33; Fax: +390461650956

\section{Keywords}

Microbial Volatile Organic Compounds, sustainable agriculture, plant growth promotion, plant protection, plant-microbe interactions.

\begin{abstract}
Current agricultural practice depends upon a wide use of pesticides, bactericides and fungicides. Increased demand for organic products indicates consumer preference for reduced chemical use. Therefore, there is a need to develop novel sustainable strategies for crop protection and
\end{abstract}


enhancement that do not rely on harmful chemicals and/or genetic modification. Microbial (bacterial and fungal) volatile organic compounds (MVOCs) are intriguingly complex and dynamic, and can modulate the physiology of plants and microorganisms by regulating metabolomics, genomics and proteomics status. Hence, MVOCs can be exploited to use as an ecofriendly, cost effective and sustainable strategy for agricultural practices. An increasing body of evidence indicates that MVOCs might become alternative to harmful pesticides, fungicides and bactericides as well as genetic modification.

\section{Introduction}

Bacteria and fungi are the major inhabitants of soil rhizosphere, the narrow zone of soil that surrounds and is influenced by plant roots and which is considered to be one of the most dynamic interfaces on Earth. In agro-ecosystems, the rhizosphere microbiota have been shown to have a profound influence on plant growth, nutrition and health [1, 2]. Numerous organisms are responsible for these processes, partaking in innumerable interactions between plants, antagonists and mutualistic symbionts, both below and above ground [3-5]. To help plants to defend against attack from multiple pathogens, sophisticated alternative interactions involving plant growth promoting rhizobacteria (PGPR) and fungi (PGPF) occur, through the activation of induced systemic resistance (ISR) [6].

Many of the current insights into the above mentioned interactions and processes have originated from direct physical contact between interacting partners. However, in the last decade considerable progress is also being made in understanding the role microbial signals and microbial volatile organic compounds (MVOCs) in below- and above-ground multitrophic interactions and their roles in modulating growth, nutrition and health of interacting partners [713].

Microorganisms produce a plethora of intriguingly complex and dynamic MVOCs, which are defined as compounds that have high enough vapor pressures under normal conditions to significantly vaporize and enter the atmosphere [1]. Despite increasing attention on the importance of MVOCs in both atmospheric ("above-ground") and soil ("below-ground") ecosystems [7, 14-17], their functional role remains elusive. Only recently, a few studies have 
shown the wealth of MVOCs for the modulation of crop growth, development, defense, interand intra-specific communication [2]. Recent literature reports the documentation of MVOCs produced by just 400 microorganisms of the 10,000 described microbial species and millions of species existing on earth [10].

At the plant-microbe community level, substantial progress has been made in studying various strains of PGPR, PGPF and phytopathogen MVOCs multifaceted role in agro-ecosystems. Chemical ecologists consider MVOCs as potential semiochemicals that function as attractants and repellants to insects and other invertebrates. For agriculture scientists, MVOCs are seen as bio-control agents to control various phytopathogens and as bio-fertilizers for plant growth promotion. In the food industries, the MVOCs bio-control properties are used to prevent postharvest plant diseases. Most recently, MVOCs have been considered as a potential source of biofuel.

Because many recent reviews have considered the multifaceted importance of MVOCs, including the regulation of VOC emissions, the role of VOC in plant rhizosphere processes (i.e. competence, pathogenesis, symbiosis) and their potential functions as quorum sensing signals both for microbial growth and regulation of root development [8-10, 18], we will not repeat this in detail. Instead, this article will focus on the role of MVOCs in plant growth, nutrients and health perspectives and possible exploitation of MVOCs significance role from lab conditions to the open field conditions. Here, we review recent progress in MVOCs research for crop welfare and suggest that a conceptual framework is needed to stimulate adoption of MVOCs at open field condition as a possible substitute for the hazardous chemical pesticides and fertilizer.

\section{MVOCs in the field for crop welfare}

Under highly competitive but symbiotic conditions, MVOCs are particularly important for antibiosis and signaling, and may serve as regulators of plant growth and development. The ecological functions of microbial volatiles are not understood in detail, but several functions such as inter and intra species communication, defense and plant growth-promotion/priming have been suggested. Research over the last 10 years has led to an increasingly clear conceptual understanding of the role MVOCs for the crop welfare. These studies demonstrated the 
modulation of metabolomics, genomics and proteomics of crop plants upon MVOCs treatment. MVOCs influence on modulation of phytohormones, induction of systemic acquired resistance, defense and priming response, multiple pathogen resistance, and change in plant biomass, growth and development have been extensively studied and reviewed elsewhere [7, 9, 14, 15, 17, 19-23]. Here, we emphasize selected examples of how microbial MVOCs modulate above mentioned multifaceted interactions.

Exposure of Arabidopsis plants to MOVOCs from rhizosphere strains of Bacillus subtilis and B. amyloliquefaciens resulted in significant growth promotion. Further investigation on the volatile profile revealed that 2,3-butanediol is the major volatile compound contributing to this phenotypic effect $[13,24]$. Similarly, exposure of tobacco plants to Pseudomonas chlororaphis MVOCs promoted growth via GacS kinase-dependent production of 2,3-butanediol [25]. These GacS kinases also regulate the synthesis of signal molecules such as acyl-homoserine lactones (AHL), suggesting that 2,3-butanediol and other MVOCs may belongs to a novel class of chemical signals that bacteria utilize to communicate with neighboring organisms [25]. $B$. subtilis emitted 2,3-butanediol contributes to salt tolerance and ISR in Arabidopsis, whereas the same compound produced by $P$. chlororaphis resulted in Arabidopsis drought tolerance and enhanced disease resistance against Erwinia caratovora but not against $P$. syringae pv. tabaci [12, 25-27]. Many other bacterial volatiles from species which are present in the plant rhizosphere, such as Burkholderia cepaci and Staphylococcus, show growth promoting features although their chemical structures are yet to be determined [21]. There are certain bacterial genera including Burkholderia, Chromobacterium, Pseudomonas, Serratia and Stenotrophomans, whose volatile profiles have shown to have adverse effects on plant growth and development $[19,22]$. Transcriptional and molecular analysis of Arabidopsis exposed to growth inhibiting volatile profiles of Serratia plymuthica and Stenotrophomnas maltophilia suggest an important role of the WRKY18 transcription factor in volatile-mediated plant growth inhibition [28]. Growth modulation, ISR and drought tolerance observed in plants after microbial volatile exposure depend on genomic, metabolomic and proteomic changes, which are largely attributed to alterations on phytohormone levels. The influence of 2,3-butanediol from B. subtilis on plant growth and ISR is due to modulation of ethylene and auxin homeostasis. Similarly, drought tolerance induced by 2,3-butanediol from $P$. chlororaphis depends on jasmonic and salicylic acid, although the involvement other phytohormones and their cross talk could not be 
ruled out [12, 13, 27, 29]. Transcriptomic, proteomic and metabolomic analyses of Arabidopsis exposed to B.subtilis suggests the involvement of different signaling pathways for enhanced growth, involving activity of cell wall modification, stress responses, hormone regulation, antioxidant enzymes activity and photosynthesis [29-31].

Similar studies were conducted to understand the role fungal volatile profile on plant growth, nutrients and health. Trichoderma viride volatiles induce significant changes in Arabidopsis, including increased lateral roots, taller, bigger and early flowering phenotypic changes [32]. 1octen-3-ol is commonly produced by many fungi and contributes to enhance plant resistance to the necrotropic fungal pathogen Botrytis cinerea by inducing defense signaling cascades [33, 34]. Alternaria alternata, Penicillium charlesii and $P$. aurantiogriseum volatile profile promote growth and starch accumulation in several plant species [35]. Interestingly, volatiles from a nonpathogenic strain of Fusarium oxysporum, MSA35, associated with a group of ectosymbiotic bacteria promotes lettuce growth [36, 37]. Further studies on this strain revealed that sequiterpenes such as $\beta$-caryophyllene produced by the ectosymbiotic bacterial species are the major volatile compounds responsible for the enhanced growth [37]. Ectomycorrhizal truffles such as Tuber borchii, T. indicum and T.melanopsorum produce volatiles that mediated inhibition of leaf growth and root development in Arabidopsis [38].

Collectively, these studies demonstrate that MVOCs have profound effects on plant metabolism, growth and health. However, many of the current insights into the role of MVOCs in modulating plant growth and defense are obtained from either laboratory or greenhouse experiments. Quite recently, a study has been conducted at the field level to induce crop defense against multiple pathogens and to attract natural enemies of aphids. This study provided useful insights of possible implementation of MVOCs as crop protection and biocontrol agents in open field conditions [39]. We now have the means to begin a new era of MVOCs that might potentially replace costly and unsustainable chemical pesticides and fertilizers and limit the use of genetically modified crops. Table 1 lists some bioactive MVOCs and their effects on plants.

\section{Deployment of MVOCs in the open field}

The search for novel molecules with biotechnological applications is termed "bioprospecting". For most of the 20th century, fungal and bacterial bioprospecting has focused on the search for 
traditional secondary metabolites with drug value (e.g. penicillin, lovastatin) or for enzymes with new applications (e.g. biomass degrading enzymes from thermophiles). A concerted search for new biotechnological products among MVOCs will require a paradigm shift in the scientific community's thinking [15]. MVOCs represent a new frontier in bioprospecting. However, although considerable progress has been made in our understanding of MVOCs for crop welfare at lab conditions, we are still far from implementing them under field conditions. Relatively recent studies conducted on volatile application at open field condition suggest that MVOCs can be applied to trigger defense against both pathogens and herbivores [39]. This is just the beginning but we still need to optimize proper conditions for the effective implementation of MVOCs at the field level.

There are many limitations of MVOCs for field applications: a) identification of bioactive MVOCs; b) optimization of concentration of specific volatiles or blend of volatile compounds; and c) application at the field level. The latter, by considering MVOCs physical and chemical properties, is the most difficult and challenging task. For instance, 2,3-butandiol field treatment on tobacco led to significant reduction in disease symptoms, whereas no significant results were observed when cucumber plants were treated to fight the biotrophic pathogen Pseudomonas syringae [39-41]. However, an artificial VOC mixture prepared on the basis of the composition of the VOCs (mainly alcohols and esters) mimicked the inhibitory effects of the natural MVOCs released by Saccharomyces cerevisiae on citrus black spot, caused by the fungus Guignardia citricarpa at postharvest. Thus, MVOCs produced by the yeast or the artificial mixtures might be a promising control method for citrus black spot or others postharvest diseases [42, 43]. So far, MVOCs are successfully applied at field level as a foliar spray and soil dumping [39-41] but there are no comparative studies using different methods of field application to provide a better understanding of effective and optimized methods.

\section{Conclusions and future perspectives}

Studies of MVOCs application at the field level are still in their infancy. More experiments and field trials are needed to prove their worth and provide sustained industry pipelines leading to a commercial production that meets farmers' needs. Consumers are well aware of the hazardous effect caused to the environment and human health by pesticides and chemical fertilizers. Alternative to this, genetically modified crop plants and recently proposed genetically edited 
crops [44] could provide a solution, but most countries have lengthy, cumbersome and expensive regulatory frameworks, which slow down the use of genetically modified crop plants. Now it is time to adopt emerging MVOCs, a new sustainable approach that can be available in a cheaper, efficient, effective and ecofriendly manner. MVOCs are equivalent to biopesticides or biofertlizers. The market breadth and demand for these naturally derived compounds increased considerably in the recent years around the world but their use is still only $4 \%$ of the global pesticide market $[45,46]$. Researchers realized the importance of MVOCs for the crop welfare under lab conditions and recently extended their studies to field level with certain success. We are now beginning to understand the multi-facet interaction of MVOCs with microorganisms and crop plants and further studies should be done by field level testing different crop species and obtaining reproducible results which could satisfy farmers' and consumers' needs. However, several questions remain unsolved (see Box 1).

In our opinion, MVOCs possess a high potential impact for crop welfare and sustainable agriculture but we are just beginning to understand their role and still far from agricultural applications. In the coming years we assume MVOCs will outperform chemical pesticides and fertilizers and will become novel candidate for sustainable agriculture.

\section{References}

1. Chaparro JM, Badri DV, Vivanco JM: Rhizosphere microbiome assemblage is affected by plant development. The ISME journal 2014, 8(4):790-803.

2. Schreiter S, Ding GC, Heuer H, Neumann G, Sandmann M, Grosch R, Kropf S, Smalla K: Effect of the soil type on the microbiome in the rhizosphere of field-grown lettuce. Frontiers in microbiology 2014, 5:144.

3. Bennett $A E$, Bever JD: Mycorrhizal species differentially alter plant growth and response to herbivory. Ecology 2007, 88(1):210-218.

4. Hol WH, de Boer W, Termorshuizen AJ, Meyer KM, Schneider JH, van Dam NM, van Veen JA, van der Putten WH: Reduction of rare soil microbes modifies plant-herbivore interactions. Ecology letters 2010, 13(3):292-301.

5. Behie SW, Zelisko PM, Bidochka MJ: Endophytic insect-parasitic fungi translocate nitrogen directly from insects to plants. Science 2012, 336(6088):1576-1577.

6. Nadeem SM, Ahmad M, Zahir ZA, Javaid A, Ashraf M: The role of mycorrhizae and plant growth promoting rhizobacteria (PGPR) in improving crop productivity under stressful environments. Biotechnology advances 2014, 32(2):429-448. 
7. Piechulla B, Degenhardt J: The emerging importance of microbial volatile organic compounds. Plant, cell \& environment 2013.

8. Ortiz-Castro R, Diaz-Perez C, Martinez-Trujillo M, del Rio RE, Campos-Garcia J, Lopez-Bucio J: Transkingdom signaling based on bacterial cyclodipeptides with auxin activity in plants. Proceedings of the National Academy of Sciences of the United States of America 2011, 108(17):7253-7258.

9. Ortiz-Castro R, Contreras-Cornejo HA, Macias-Rodriguez L, Lopez-Bucio J: The role of microbial signals in plant growth and development. Plant signaling \& behavior 2009, 4(8):701-712.

10. Ortiz-Castro R, Martinez-Trujillo M, Lopez-Bucio J: N-acyl-L-homoserine lactones: a class of bacterial quorum-sensing signals alter post-embryonic root development in Arabidopsis thaliana. Plant, cell \& environment 2008, 31(10):1497-1509.

11. Ortiz-Castro R, Valencia-Cantero E, Lopez-Bucio J: Plant growth promotion by Bacillus megaterium involves cytokinin signaling. Plant signaling \& behavior 2008, 3(4):263-265.

12. Ryu CM, Farag MA, Hu CH, Reddy MS, Kloepper JW, Pare PW: Bacterial volatiles induce systemic resistance in Arabidopsis. Plant physiology 2004, 134(3):1017-1026.

13. Ryu CM, Farag MA, Hu CH, Reddy MS, Wei HX, Pare PW, Kloepper JW: Bacterial volatiles promote growth in Arabidopsis. Proceedings of the National Academy of Sciences of the United States of America 2003, 100(8):4927-4932.

14. Effmert U, Kalderas J, Warnke R, Piechulla B: Volatile mediated interactions between bacteria and fungi in the soil. Journal of chemical ecology 2012, 38(6):665-703.

15. Shannon U. Morath RH, Joan W. Bennett: Fungal volatile organic compounds: A review with emphasis on their biotechnological potential. Fungal Biology Reviews 2012, 26(2-3):73-83.

16. Junker RR, Tholl D: Volatile organic compound mediated interactions at the plant-microbe interface. Journal of chemical ecology 2013, 39(7):810-825.

17. Bitas V, Kim HS, Bennett JW, Kang S: Sniffing on microbes: diverse roles of microbial volatile organic compounds in plant health. Molecular plant-microbe interactions : MPMI 2013, 26(8):835-843.

18. Chernin L, Toklikishvili N, Ovadis M, Kim S, Ben-Ari J, Khmel I, Vainstein A: Quorum-sensing quenching by rhizobacterial volatiles. Environmental microbiology reports 2011, 3(6):698-704.

19. Bailly $A$, Weisskopf $L$ : The modulating effect of bacterial volatiles on plant growth: current knowledge and future challenges. Plant signaling \& behavior 2012, 7(1):79-85.

20. Bennett JW, Hung R, Lee S, Padhi S: $\mathbf{1 8}$ Fungal and Bacterial Volatile Organic Compounds: An Overview and Their Role as Ecological Signaling Agents. In: Fungal Associations. Edited by Hock B, vol. 9: Springer Berlin Heidelberg; 2012: 373-393.

21. Vespermann A, Kai M, Piechulla B: Rhizobacterial volatiles affect the growth of fungi and Arabidopsis thaliana. Applied and environmental microbiology 2007, 73(17):5639-5641.

22. Kai M, Haustein M, Molina F, Petri A, Scholz B, Piechulla B: Bacterial volatiles and their action potential. Applied microbiology and biotechnology 2009, 81(6):1001-1012.

23. Penuelas J, Asensio D, Tholl D, Wenke K, Rosenkranz M, Piechulla B, Schnitzler JP: Biogenic volatile emissions from the soil. Plant, cell \& environment 2014.

24. Farag MA, Ryu CM, Sumner LW, Pare PW: GC-MS SPME profiling of rhizobacterial volatiles reveals prospective inducers of growth promotion and induced systemic resistance in plants. Phytochemistry 2006, 67(20):2262-2268.

25. Han SH, Lee SJ, Moon JH, Park KH, Yang KY, Cho BH, Kim KY, Kim YW, Lee MC, Anderson AJ et al: GacS-dependent production of 2R, 3R-butanediol by Pseudomonas chlororaphis $\mathbf{0 6}$ is a major determinant for eliciting systemic resistance against Erwinia carotovora but not against Pseudomonas syringae pv. tabaci in tobacco. Molecular plant-microbe interactions : MPMI 2006, 19(8):924-930. 
26. Zhang H, Kim MS, Sun Y, Dowd SE, Shi H, Pare PW: Soil bacteria confer plant salt tolerance by tissue-specific regulation of the sodium transporter HKT1. Molecular plant-microbe interactions : MPMI 2008, 21(6):737-744.

27. Cho SM, Kang BR, Han SH, Anderson AJ, Park JY, Lee YH, Cho BH, Yang KY, Ryu CM, Kim YC: 2R,3R-butanediol, a bacterial volatile produced by Pseudomonas chlororaphis 06 , is involved in induction of systemic tolerance to drought in Arabidopsis thaliana. Molecular plant-microbe interactions: MPMI 2008, 21(8):1067-1075.

28. Wenke K, Wanke D, Kilian J, Berendzen K, Harter K, Piechulla B: Volatiles of two growthinhibiting rhizobacteria commonly engage AtWRKY18 function. The Plant journal : for cell and molecular biology 2012, 70(3):445-459.

29. Zhang H, Kim MS, Krishnamachari V, Payton P, Sun Y, Grimson M, Farag MA, Ryu CM, Allen R, Melo IS et al: Rhizobacterial volatile emissions regulate auxin homeostasis and cell expansion in Arabidopsis. Planta 2007, 226(4):839-851.

30. Kwon YS, Ryu CM, Lee S, Park HB, Han KS, Lee JH, Lee K, Chung WS, Jeong MJ, Kim HK et al: Proteome analysis of Arabidopsis seedlings exposed to bacterial volatiles. Planta 2010, 232(6):1355-1370.

31. Zhang H, Xie X, Kim MS, Kornyeyev DA, Holaday S, Pare PW: Soil bacteria augment Arabidopsis photosynthesis by decreasing glucose sensing and abscisic acid levels in planta. The Plant journal : for cell and molecular biology 2008, 56(2):264-273.

32. Hung R, Lee $S$, Bennett JW: Arabidopsis thaliana as a model system for testing the effect of Trichoderma volatile organic compounds. Fungal Ecology 2013, 6(1):19-26.

33. Kishimoto K, Matsui K, Ozawa R, Takabayashi J: Volatile 1-octen-3-ol induces a defensive response in Arabidopsis thaliana. J Gen Plant Pathol 2007, 73(1):35-37.

34. Contreras-Cornejo H, Macías-Rodríguez L, Herrera-Estrella A, López-Bucio J: The 4phosphopantetheinyl transferase of Trichoderma virens plays a role in plant protection against Botrytis cinerea through volatile organic compound emission. Plant Soil 2014, 379(12):261-274.

35. Ezquer I, Li J, Ovecka M, Baroja-Fernandez E, Munoz FJ, Montero M, Diaz de Cerio J, Hidalgo M, Sesma MT, Bahaji A et al: Microbial volatile emissions promote accumulation of exceptionally high levels of starch in leaves in mono- and dicotyledonous plants. Plant \& cell physiology 2010, 51(10):1674-1693.

36. Minerdi D, Bossi S, Gullino ML, Garibaldi A: Volatile organic compounds: a potential direct longdistance mechanism for antagonistic action of Fusarium oxysporum strain MSA 35. Environmental microbiology 2009, 11(4):844-854.

37. Minerdi D, Bossi S, Maffei ME, Gullino ML, Garibaldi A: Fusarium oxysporum and its bacterial consortium promote lettuce growth and expansin A5 gene expression through microbial volatile organic compound (MVOC) emission. FEMS microbiology ecology 2011, 76(2):342-351.

38. Splivallo R, Novero M, Bertea CM, Bossi S, Bonfante P: Truffle volatiles inhibit growth and induce an oxidative burst in Arabidopsis thaliana. The New phytologist 2007, 175(3):417-424.

39. Song GC, Ryu CM: Two Volatile Organic Compounds Trigger Plant Self-Defense against a Bacterial Pathogen and a Sucking Insect in Cucumber under Open Field Conditions. International journal of molecular sciences 2013, 14(5):9803-9819.

40. Cortes-Barco AM, Goodwin PH, Hsiang T: Comparison of induced resistance activated by benzothiadiazole, (2R,3R)-butanediol and an isoparaffin mixture against anthracnose of Nicotiana benthamiana. Plant Pathology 2010, 59(4):643-653.

41. Cortes-Barco AM, Hsiang T, Goodwin PH: Induced systemic resistance against three foliar diseases of Agrostis stolonifera by (2R,3R)-butanediol or an isoparaffin mixture. Annals of Applied Biology 2010, 157(2):179-189. 
42. Fialho MB, Ferreira LFR, Monteiro RTR, Pascholati SF: Antimicrobial volatile organic compounds affect morphogenesis-related enzymes in Guignardia citricarpa, causal agent of citrus black spot. Biocontrol Science and Technology 2011, 21(7):797-807.

43. Fialho M, Toffano L, Pedroso M, Augusto F, Pascholati S: Volatile organic compounds produced by Saccharomyces cerevisiae inhibit the in vitro development of Guignardia citricarpa, the causal agent of citrus black spot. World Journal of Microbiology and Biotechnology 2010, 26(5):925-932.

44. Nagamangala Kanchiswamy C, Sargent DJ, Velasco R, Maffei ME, Malnoy M: Looking forward to genetically edited fruit crops. Trends in biotechnology 2014.

45. Glare T, Caradus J, Gelernter W, Jackson T, Keyhani N, Kohl J, Marrone P, Morin L, Stewart A: Have biopesticides come of age? Trends in biotechnology 2012, 30(5):250-258.

46. Wilson K, Benton TG, Graham RI, Grzywacz D: Pest control: biopesticides' potential. Science 2013, 342(6160):799.

47. Velázquez-Becerra C, Macías-Rodríguez L, López-Bucio J, Altamirano-Hernández J, Flores-Cortez I, Valencia-Cantero E: A volatile organic compound analysis from Arthrobacter agilis identifies dimethylhexadecylamine, an amino-containing lipid modulating bacterial growth and Medicago sativa morphogenesis in vitro. Plant Soil 2011, 339(1-2):329-340.

48. Zou C, Li Z, Yu D: Bacillus megaterium strain XTBG34 promotes plant growth by producing 2pentylfuran. Journal of microbiology 2010, 48(4):460-466.

49. Blom D, Fabbri C, Eberl L, Weisskopf L: Volatile-mediated killing of Arabidopsis thaliana by bacteria is mainly due to hydrogen cyanide. Applied and environmental microbiology 2011, 77(3):1000-1008.

50. Åström B, Gerhardson B: Wheat cultivar reactions to deleterious rhizosphere bacteria under gnotobiotic conditions. Plant Soil 1989, 117(2):157-165.

51. Blom D, Fabbri C, Connor EC, SchiestI FP, Klauser DR, Boller T, Eberl L, Weisskopf L: Production of plant growth modulating volatiles is widespread among rhizosphere bacteria and strongly depends on culture conditions. Environmental microbiology 2011, 13(11):3047-3058.

52. Gutiérrez-Luna F, López-Bucio J, Altamirano-Hernández J, Valencia-Cantero E, de la Cruz H, Macías-Rodríguez L: Plant growth-promoting rhizobacteria modulate root-system architecture in Arabidopsis thaliana through volatile organic compound emission. Symbiosis 2010, 51(1):7583.

53. Wheatley RE: The consequences of volatile organic compound mediated bacterial and fungal interactions. Antonie van Leeuwenhoek 2002, 81(1-4):357-364.

54. Scholler CE, Gurtler H, Pedersen R, Molin S, Wilkins K: Volatile metabolites from actinomycetes. Journal of agricultural and food chemistry 2002, 50(9):2615-2621.

55. Funes $\mathrm{H}$, Zerba E, Gonzalez Audino P: Comparison of three types of traps baited with sexual pheromones for ambrosia beetle Megaplatypus mutatus (Coleoptera: Platypodinae) in poplar plantations. Journal of economic entomology 2009, 102(4):1546-1550.

56. Manrique G, Vitta AC, Ferreira RA, Zani CL, Unelius CR, Lazzari CR, Diotaiuti L, Lorenzo MG: Chemical communication in Chagas disease vectors. Source, identity, and potential function of volatiles released by the metasternal and Brindley's glands of Triatoma infestans adults. Journal of chemical ecology 2006, 32(9):2035-2052.

57. Vitta AC, Lorenzo MG: Copulation and mate guarding behavior in Triatoma brasiliensis (Hemiptera: Reduviidae). Journal of medical entomology 2009, 46(4):789-795.

58. Bukovinszky T, Gols R, Posthumus MA, Vet LE, Van Lenteren JC: Variation in plant volatiles and attraction of the parasitoid Diadegma semiclausum (Hellen). Journal of chemical ecology 2005, 31(3):461-480. 
59. Strobel GA, Dirkse E, Sears J, Markworth C: Volatile antimicrobials from Muscodor albus, a novel endophytic fungus. Microbiology 2001, 147(Pt 11):2943-2950.

60. Mitchell AM, Strobel GA, Moore E, Robison R, Sears J: Volatile antimicrobials from Muscodor crispans, a novel endophytic fungus. Microbiology 2010, 156(Pt 1):270-277.

61. Singh SK, Strobel GA, Knighton B, Geary B, Sears J, Ezra D: An endophytic Phomopsis sp. possessing bioactivity and fuel potential with its volatile organic compounds. Microbial ecology 2011, 61(4):729-739.

62. Strobel G, Singh SK, Riyaz-UI-Hassan S, Mitchell AM, Geary B, Sears J: An endophytic/pathogenic Phoma sp. from creosote bush producing biologically active volatile compounds having fuel potential. FEMS microbiology letters 2011, 320(2):87-94.

63. Macias-Rubalcava ML, Hernandez-Bautista BE, Oropeza F, Duarte G, Gonzalez MC, Glenn AE, Hanlin RT, Anaya AL: Allelochemical effects of volatile compounds and organic extracts from Muscodor yucatanensis, a tropical endophytic fungus from Bursera simaruba. Journal of chemical ecology 2010, 36(10):1122-1131.

64. Mercier J, Jiménez JI: Control of fungal decay of apples and peaches by the biofumigant fungus Muscodor albus. Postharvest Biology and Technology 2004, 31(1):1-8.

65. Thakeow P, Angeli S, Weißbecker B, Schütz S: Antennal and Behavioral Responses of Cis boleti to Fungal Odor of Trametes gibbosa. Chemical Senses 2008, 33(4):379-387.

66. Drilling K, Dettner K: Electrophysiological responses of four fungivorous coleoptera to volatiles of Trametes versicolor: implications for host selection. Chemoecology 2009, 19(2):109-115. 
Table 1. List of bioactive MVOCs and their effects on plants

\begin{tabular}{|c|c|c|c|}
\hline $\begin{array}{l}\text { Bacterial or } \\
\text { Fungal species } \\
\text { and strain }\end{array}$ & Identified volatile compounds & Effects on interacting organisms & Ref. \\
\hline $\begin{array}{c}\text { Arthobacter agilis } \\
\text { UMCV2 }\end{array}$ & $\mathrm{N}, \mathrm{N}$-dimethyl-hexadecanamine & Growth promotion & {$[47]$} \\
\hline $\begin{array}{l}\text { Bacillus } \\
\text { amyloliquefaciens } \\
\text { IN937a }\end{array}$ & 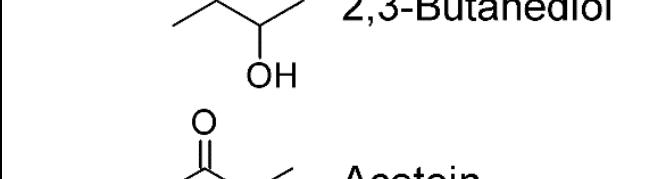 & $\begin{array}{l}\text { Growth promotion and induced systemic } \\
\text { resistance (ISR) }\end{array}$ & $\begin{array}{c}{[12} \\
13]\end{array}$ \\
\hline $\begin{array}{l}\text { Bacillus } \\
\text { megaterium } \\
\text { XTBG34 }\end{array}$ & 2-penthylfuran & Growth promotion & {$[48]$} \\
\hline $\begin{array}{l}\text { Bacillus subtilis } \\
\text { GBO3 }\end{array}$ & $\mathrm{H}$ & Growth promotion and ISR & $\begin{array}{c}{[12,} \\
13]\end{array}$ \\
\hline
\end{tabular}




\begin{tabular}{|c|c|c|c|}
\hline $\begin{array}{l}\text { Bacterial or } \\
\text { Fungal species } \\
\text { and strain }\end{array}$ & Identified volatile compounds & Effects on interacting organisms & Ref. \\
\hline $\begin{array}{l}\text { Fusarium } \\
\text { oxysporum } \\
\text { MSA } 35\end{array}$ & $\beta \sum$ & $\begin{array}{l}\text { Induced shoot length, root length and fresh } \\
\text { weight of lettuce seedlings }\end{array}$ & [37] \\
\hline $\begin{array}{l}\text { Many species of } \\
\text { bacteria, fungi and } \\
\text { plants }\end{array}$ & & $\begin{array}{l}\text { ISR, emission of green leaf volatiles to attract } \\
\text { natural enemies of Aphid }\end{array}$ & $\begin{array}{l}{[24,} \\
39 \\
53 \\
54]\end{array}$ \\
\hline $\begin{array}{l}\text { Many species of } \\
\text { bacteria, fungi and } \\
\text { plants }\end{array}$ & & $\begin{array}{l}\text { ISR, pheromone, in response to herbivore } \\
\text { produced by plant to attract natural enemies }\end{array}$ & $\begin{array}{l}{[39} \\
55- \\
58]\end{array}$ \\
\hline Mold fungi & 3-ol & $\begin{array}{l}\text { Induced defense and protection against } \\
\text { Botrytis cinerea }\end{array}$ & [33] \\
\hline Muscodor albus & Isoamyl acetate & $\begin{array}{c}\text { Collectively they acted synergistically to kill a } \\
\text { broad range of plant- and human-pathogenic } \\
\text { fungi and bacteria }\end{array}$ & [59] \\
\hline
\end{tabular}




\begin{tabular}{|c|c|c|c|}
\hline $\begin{array}{l}\text { Bacterial or } \\
\text { Fungal species } \\
\text { and strain }\end{array}$ & Identified volatile compounds & Effects on interacting organisms & Ref. \\
\hline Muscodor albus & 2-methyl butanol isobutyric acid & $\begin{array}{l}\text { Volatile mixture were effectively used to } \\
\text { control postharvest plant diseases }\end{array}$ & [64] \\
\hline $\begin{array}{l}\text { Muscodor } \\
\text { crispans }\end{array}$ & Mixture of volatile compounds & $\begin{array}{l}\text { Effective against a wide range of plant } \\
\text { pathogens, including the fungi Pythium } \\
\text { ultimum, Phytophthora cinnamomi, } \\
\text { Sclerotinia sclerotiorum and Mycosphaerella } \\
\text { fijiensis (the black sigatoka pathogen of } \\
\text { bananas), and the serious bacterial pathogen of } \\
\text { citrus, Xanthomonas axonopodis pv. citri. In } \\
\text { addition, the VOCs of M. crispans killed } \\
\text { several human pathogens, including Yersinia } \\
\text { pestis, Mycobacterium tuberculosis and } \\
\text { Staphylococcus aureus. }\end{array}$ & {$[60]$} \\
\hline $\begin{array}{l}\text { Muscodor } \\
\text { yucatanensis }\end{array}$ & Mixture of volatile organic compounds & $\begin{array}{l}\text { Mixture of volatile organic compounds } \\
\text { produced by } M . \text { yucatanensis have } \\
\text { allelochemical effects against other } \\
\text { endophytic fungi, phytopathogenic fungi and } \\
\text { plants. }\end{array}$ & [63] \\
\hline Phoma sp & $\begin{array}{l}\text { Unique mixture of volatile organic } \\
\text { compounds, including a series of } \\
\text { sesquiterpenoids, some alcohols and several } \\
\text { reduced naphthalene derivatives. }\end{array}$ & $\begin{array}{l}\text { The volatiles of Phoma sp. possess antifungal } \\
\text { and fuel properties Some of the test organisms } \\
\text { with the greatest sensitivity to the Phoma sp. } \\
\text { Volatiles were Verticillium, Ceratocystis, } \\
\text { Cercospora and Sclerotinia. }\end{array}$ & {$[62]$} \\
\hline
\end{tabular}




\begin{tabular}{|c|c|c|c|}
\hline $\begin{array}{c}\text { Bacterial or } \\
\text { Fungal species } \\
\text { and strain }\end{array}$ & Identified volatile compounds & Effects on interacting organisms & Ref. \\
\hline Phomopsis sp & 2-propanone propanol & $\begin{array}{l}\text { Volatile mixture of Phomopsis sp. possess } \\
\text { antifungal properties and an artificial mixture } \\
\text { of the VOCs mimicked the antibiotic effects } \\
\text { of this organism with the greatest bioactivity } \\
\text { against a wide range of plant pathogenic test } \\
\text { fungi including: Pythium, Phytophthora, } \\
\text { Sclerotinia, Rhizoctonia, Fusarium, Botrytis, } \\
\text { Verticillium, and Colletotrichum. }\end{array}$ & [61] \\
\hline $\begin{array}{c}\text { Pseudomanas } \\
\text { aeruginosa } \\
\text { PAO1, PAO14, } \\
\text { Tb, TBCF10839 } \\
\text { and PUPa3 }\end{array}$ & $\mathrm{HCN}$ & Growth inhibition & [49] \\
\hline $\begin{array}{l}\text { Pseudomanas } \\
\text { chlororaphis } \mathrm{O} 6\end{array}$ & 2,3-Butanediol & $\begin{array}{l}\text { Growth promotion, ISR and drought stress } \\
\text { tolerant }\end{array}$ & $\begin{array}{l}{[25,} \\
27]\end{array}$ \\
\hline $\begin{array}{l}\text { Pseudomanas } \\
\text { fluorescens } \\
\text { A112 }\end{array}$ & tetermined & Growth inhibition (shoot and root) & {$[50]$} \\
\hline Pseudomanas & Not determined & Growth inhibition & {$[21]$} \\
\hline
\end{tabular}




\begin{tabular}{|c|c|c|c|}
\hline $\begin{array}{l}\text { Bacterial or } \\
\text { Fungal species } \\
\text { and strain }\end{array}$ & Identified volatile compounds & Effects on interacting organisms & Ref. \\
\hline $\begin{array}{l}\text { trivialis } \\
\text { 3Re2-7 }\end{array}$ & & 8 & \\
\hline $\begin{array}{c}\text { Rhizosphere } \\
\text { strains (isolated } \\
\text { from rhizosphere } \\
\text { of lemon plants) } \\
\text { L263, L266, L272a, } \\
\text { L254, L265a and } \\
\text { L265b }\end{array}$ & Volatile mixture & $\begin{array}{l}\text { Growth promoting and modulation of root } \\
\text { architecture }\end{array}$ & {$[52]$} \\
\hline $\begin{array}{c}\text { Rhizosphere } \\
\text { strains (more than } \\
42 \text { strains } \\
\text { predominantly } \\
\text { from } \\
\text { Burkholderia } \\
\text { genus) }\end{array}$ & Not determ & $\begin{array}{l}\text { Growth inhibition or promotion (dose } \\
\text { dependent) }\end{array}$ & {$[51]$} \\
\hline $\begin{array}{c}\text { Serratia } \\
\text { marcescens } \\
\text { MG-1 }\end{array}$ & Not determined & Growth inhibition & [21] \\
\hline $\begin{array}{c}\text { Serratia } \\
\text { plymuthica } \\
\text { 3Re4-18, HRO- } \\
\text { C48, IC14 }\end{array}$ & Not determined & Growth inhibition & $\begin{array}{l}{[21,} \\
49]\end{array}$ \\
\hline
\end{tabular}




\begin{tabular}{|c|c|c|c|}
\hline $\begin{array}{l}\text { Bacterial or } \\
\text { Fungal species } \\
\text { and strain }\end{array}$ & Identified volatile compounds & Effects on interacting organisms & Ref. \\
\hline $\begin{array}{c}\text { Stenotrophomanas } \\
\text { maltophilia } \\
\text { R3089 }\end{array}$ & Not determined & Growth inhibition & [21] \\
\hline $\begin{array}{l}\text { Stenotrophomanas } \\
\text { rhizospehila } \\
\text { P69 }\end{array}$ & Not determined & Growth inhibition & [21] \\
\hline Trametes gibbosa & 1-octen-3-ol & Serves as attractant for fungus eating beetles & {$[65]$} \\
\hline $\begin{array}{l}\text { Trametes } \\
\text { versicolor }\end{array}$ & Isoledene & Serves as attractant for fungus eating beetles & [66] \\
\hline
\end{tabular}




\begin{tabular}{|c|c|c|}
$\begin{array}{c}\text { Bacterial or } \\
\begin{array}{c}\text { Fungal species } \\
\text { and strain }\end{array}\end{array}$ & Effects on interacting organisms \\
\hline $\begin{array}{c}\text { Trichoderma } \\
\text { virens }\end{array}$
\end{tabular}




\section{Outstanding Questions Box 1}

VOCs play important signaling roles for bacteria and fungi but also for other organisms in their natural environments. Many ecological interactions are mediated by VOCs, including those between fungi and plant, bacteria and plants, plant-plants, arthropods-plants, ect. The diverse functions of MVOCs can be exploited in biotechnological applications for biofuel, biocontrol, and mycofumigation. MVOCs represent a new frontier in bioprospecting, and the study of these gas-phase compounds promises the discovery of new products for human exploitation (medical, agricultural and industrial arenas) and will generate new hypotheses in fundamental biology. However, the mechanisms through which MVOC respond to their surrounding must be better understood in order to be more predictive about which role and effect on their surrounding. Some key questions remain to be answered:

- What is the advantage of the plant to perceive (M)VOCs?

- Which plant proteins participate in the perception of MVOCs?

- What is the identity of MVOCs responsible for induction of plant growth/defense?

- Are plants able to perceive MVOCs from their bacterial and fungal pathogens, and are they able to induce defense mechanism?

- Are plants able make the difference between MVOCs produce by host or non host pathogens?

- Can MVOCs be used as biopesticides? 


\section{Glossary}

Above-ground: a position measured with respect to the underlying ground surface.

Agrochemicals: a generic term for the various chemical products used in agriculture. In most cases, agrichemical refers to the broad range of pesticides, including insecticides, herbicides, and fungicides. It may also include synthetic fertilizers, hormones and other chemical growth agents, and concentrated stores of raw animal manure.

Below-ground: a position measured with respect to the upper ground surface.

Biofertlizer: a substance containing living microorganisms which, when applied to seed, plant surfaces, or soil, colonizes the rhizosphere or the interior of the plant and promotes growth by increasing the supply or availability of primary nutrients to the host plant.

Biofilm: any group of microorganisms in which cells stick to each other on a surface.

Biopesticides: include several types of pest management intervention: through predatory, parasitic, or chemical relationships. The term has been associated historically with biological control and the manipulation of living organisms.

Bioprospecting: the search for new natural and sustainable molecules in the hope of finding novel biotechnological applications

Crop welfare: is the provision of a minimal level of well-being and social support for all crops.

Info-chemical: information-conveying chemicals including kairomones, allelochemicals or pheromones that play a crucial role in food web interactions.

Microorganism: a very diverse kingdom that includes all the bacteria and archaea and almost all the protozoa. They also include some members of the fungi, algae, and animals such as rotifers.

Multitrophic interactions: incorporation of species from different trophic or nutritional levels interacting in the same system.

MVOCs: microbial volatile organic compounds that have high enough vapor pressures under normal conditions to significantly vaporize and enter the atmosphere.

Mycofumigation: the use of gas-producing fungi to kill other microorganisms via production of MVOCs.

Plant growth inhibition: reduction of plant growth determined by environmental factors, such as temperature, available water, available light, carbon dioxide and available nutrients in the soil or by the actions of pathogenic and saprophytic organisms and herbivores.

Priming: exposure to conditions by which the processing of a target stimulus is aided or altered by the presentation of a previously presented stimulus.

Rhizobacteria: root-colonizing bacteria that form symbiotic relationships with many plants. Though parasitic varieties of rhizobacteria exist, the term usually refers to bacteria that form a relationship beneficial for both parties (mutualism). 
Rhizosphere: a narrow region of soil that is directly influenced by root secretions and associated soil microorganisms. It contains many bacteria that feed on sloughed-off plant cells, termed rhizodeposition, and the proteins and sugars released by roots.

Sustainable agriculture: an integrated system of plant and animal production practices having a site-specific application that will last over the long term. 